\title{
APLIKASI PUPUK ORGANIK UNTUK MENINGKATKAN PERTUMBUHAN BIBIT JAMBU METE (Anacardium occidentale L.)
}

\author{
Ahmad Raksun \\ Dosen Program Studi Pendidikan Biologi FKIP UNRAM
}

\begin{abstract}
ABSTRAK
Penelitian tentang aplikasi pupuk organik untuk meningkatkan pertumbuhan bibit Jambu Mete telah dilaksanakan di Desa Pijot Kabupaten Lombok Timur. Penelitian ini bertujuan untuk mengetahui: (1) pengaruh aplikasi pupuk organik terhadap pertumbuhan bibit Jambu Mete, (2) dosis pupuk organik agar bibit Jambu Mente dapat tumbuh secara optimal. Dalam penelitian ini digunakan rancangan acak lengkap dengan tiga ulangan. Hasil penelitian menunjukkan bahwa (1) pemberian pupuk organik dapat meningkatkan pertumbuhan bibit Jambu Mete, (2) Penggunaan dosis pupuk organik 2,0 kg/12 kg tanah memberikan hasil yang lebih baik dibandingkan perlakuan lainnya.
\end{abstract}

Kata-kata kunci: Pupuk organik, pertumbuhan, jambu mete

\section{THE APLICATION OF ORGANIC FERTILIZER TO INCREAST THE GROWTH OF CASHEW SEEDLING}

\begin{abstract}
Ahmad Raksun
ABSTRACT

A research about the application of organic fertilizer to increase the growth of cashew seedling has done in Pijot Village East Lombok. The purpose of this research are: (1) to know the effect of organic fertilizer to the growth of cashew seedling, (2) to know the dose of organic fertilizer in oder that cashew seedling can grow optimally. Complately randomized design with three replicates were used in this research. The result of this research are: (1) the application of organic fertilizer can increas the growth of cashew seedling, (2) Aplication 2,0 kg organic fertilizer/12 kg soil cause the better growth than other treatment.
\end{abstract}

Key Words: organic fertilizer, growth, cashew 


\section{PENDAhuluan}

Keberadaan sampah di sekitar kita dapat mengurangi estetika lingkungan. Di wilayah perkotaan khususnya pada wilayah pemukiman padat penduduk sering ditemukan sampah dalam jumlah banyak. Sampahsampah tersebut disamping mengurangi estetika lingkungan, juga dapat menimbulkan bau tak sedap dan menutup saluran air sehingga keberadaan sampah dapat menjadi penyebab terjadinya banjir pada musim hujan.

Di berbagai wilayah di Indonesia telah dikembangkan berbagai teknik penanganan sampah, salah satu diantaranya adalah dengan memanfaatkan sampah sebagai bahan baku pembuatan pupuk organik. Pengolahan sampah sebagai bahan baku pembuatan pupuk organik memungkinkan lingkungan di sekitar kita menjadi bersih, indah dan sehat. Selain itu hasil dekomposisi sampah tersebut dapat dimanfaatkan untuk meningkatkan kesuburan tanah dan meningkatkan pertumbuhan tanaman.

Aplikasi pupuk organik pada lahan pertanian memiliki berbagai manfaat. Joetono (1995) menjelaskan, bahwa di dalam tanah, bahan organik mempunyai peran dalam memeperbaiki sifat fisika dan kimia tanah melalui stabilitas struktur, infiltrasi air, kadar air, drainase, suhu, aktivitas mikrobia dan penetrasi akar. Terhadap sifat kimia tanah, secara umum berpengaruh tarhadap penyediaan hara bagi tumbuhan dan merupakan sumber hara N, P dan S. Berbagai hasil penelitian menunjukkan, bahwa pemanfaatan pupuk organik pada lahan pertanian berdampak positif terhadap ketersedian hara, pertumbuhan dan produksi tanaman. Hasil penelitian yang dilakukan oleh Kadir dan Kanro (2006) menunjukkan, bahwa pemberian pupuk organik berpengaruh terhadap perbaikan komponen pertumbuhan, komponen produksi kopi dan estimasi produksi. Pemberian pupuk organik bokashi S. Molesta dan pupuk kandang ayam berpengaruh nyata dalam meningkatkan semua parameter pertumbuhan dan produksi tanaman kedelai (Kumalasari, 2011). Pupuk organik super nasa berpengaruh sangat nyata terhadap tinggi batang setelah 45 hari penanaman, berat kering biji per plot dan berat kering biji per hektar (Marliah dkk, 2011). Pemberian pupuk organik bokashi kotoran sapi dan eceng gondok dapat meningkatkan bobot berangkasan tanaman tomat (Soverda dkk, 2008). Bibit cendana yang ditumbuhkan pada media organik mempunyai nilai indeks mutu yang nisbi sama dengan media tanah atasan/topsoil (Putri, 2008). Pemberian berbagai dosis pupuk organik bokashi berpengaruh nyata terhadap tinggi tanaman kedelai (Simaptupang, 1999)

Untuk mengetahui pengaruh
aplikasi pupuk organik terhadap pertumbuhan bibit jambu mete maka peneliti melakukan penelitian tentang aplikasi pupuk organik untuk 
meningkatkan pertumbuhan jambu mete yang dilakukan di Desa Pijot Kabupaten Lombok Timur. Adapun tujuan dilaksanakannya penelitian ini adalah untuk mengetahui: (1) pengaruh pemberian pupuk organik terhadap pertumbuhan bibit Jambu Mente, (2) dosis pupuk organik agar bibit Jambu Mente dapat tumbuh secara optimal.

\section{BAHAN DAN METODE}

\subsection{Pembuatan Pupuk Organik.}

Dalam pembuatan pupuk organik bahan yang digunakan adalah sampah organik (daun tumbuhan), sekam (kulit padi), kotoran sapi, tanah dan air. Sedangkan alat yang digunakan adalah ember plastik, cangkul, karung goni, parang, sekop, sendok, neraca dan gelas ukur. Selanjutnya langkah kerja dalam pembuatan pupuk organik (Teruo, 1999) adalah: (1) memisahkan sampah organik (daun tumbuhan) dari sampah yang lainnya, (2) mencincang sampah organik dengan ukuran $2 \mathrm{~cm}$, (3) mencampur sampah organik yang sudah dicincang dengan sekam dengan perbandingan 4 : 1, (4) membuat galian lubang dengan ukuran $100 \mathrm{~cm}$ x $100 \mathrm{~cm}$ dan kedalaman $120 \mathrm{~cm}$ (5) meletakkan campuran sampah organik sekam yang sudah dibasahi ke dalam lubang yang sudah disediakan setebal $12 \mathrm{~cm}$, meletakkan kotoran sapi yang sudah dibasahi di atas campuran sampah organik sekam setebal $6 \mathrm{~cm}$, (7) mengaduk campuran di atas sampai rata, (8) mengulangi langkah 5, 6 dan 7 sampai $80 \%$ lubang galian terisi bahan pupuk organik, (9) menutup campuran tersebut dengan karung goni dan sedikit tanah, (10)mengaduk campuran tersebut sekali sehari.

\subsection{Aplikasi Pupuk Organik pada}

\section{Pembibitan Jambu Mete}

Bahan-bahan yg digunakan pada saat aplikasi pupuk organik di lahan pertanian adalah tanah sebagai media tanam, bahan-bahan pembuatan rumah kaca sederhana (tali rapia plastik transparan, bambu, dan besi paku), benih jambu mente dan kertas label. Sedangkan alat-alat yang digunakan adalah pot plastik, timbangan, parang, alat tulis menulis, cangkul, ember plastik, palu, dan gunting.

Media tanam yang digunakan adalah campuran tanah sawah dan pupuk organik. Tanah diambil dari lahan pertanian Desa Pijot, selanjutnya dikeringkan, dibersihkan dari batu dan sisa tanaman dan diayak. Tanah ditimbang dan dimasukkan ke dalam polybag sebanyak $12 \mathrm{~kg}$ untuk setiap polybag. Tanah dalam polybag dicampur dengan pupuk organik secara merata dengan kadar sesuai perlakuan. Selanjutnya campuran media tersebut diberi air sebanyak 2 liter untuk setiap polybag dan dibiarkan selama 1 minggu. Setelah satu minggu aplikasi pupuk organik dilakukan penanaman benih jambu mete, pada setiap unit percobaan ditanami 4 benih jambu mete. Setelah 14 hari penanaman dilakukan seleksi dengan menyisakan hanya 1 bibit jambu mete yang pertumbuhannya homogen, sedangkan yang lain dihilangkan.

Percobaan dalam penelitian ini dilakukan dengan rancangan acak 
lengkap dengan tiga ulangan. Aplikasi pupuk organik terdiri atas 14 level yaitu: $\mathrm{P}_{\mathrm{o}}=$ tanpa pemberian bokashi (kontrol), $\mathrm{P}_{1}=$ pemberian $0,2 \mathrm{~kg}$ bokashi $/ 12 \mathrm{~kg}$ tanah, $\mathrm{P}_{2}=$ pemberian $0,4 \mathrm{~kg}$ bokashi $/ 12$ $\mathrm{kg}$ tanah, $\mathrm{P}_{3}=$ pemberian $0,6 \mathrm{~kg}$ bokashi/ $12 \mathrm{~kg}$ tanah, $\mathrm{P}_{4}=$ pemberian 0,8 $\mathrm{kg}$ bokashi/12 $\mathrm{kg}$ tanah, $\mathrm{P}_{5}=$ pemberian $1,0 \mathrm{~kg}$ bokashi $/ 12 \mathrm{~kg}$ tanah, $\mathrm{P}_{6}=$ pemberian $1,2 \mathrm{~kg}$ bokashi $/ 12 \mathrm{~kg}$ tanah, $\mathrm{P}_{7}=$ pemberian $1,4 \mathrm{~kg}$ bokashi $/ 12 \mathrm{~kg}$ tanah, $\mathrm{P}_{8}=$ pemberian $1,6 \mathrm{~kg}$ bokashi $/ 12$ $\mathrm{kg}$ tanah dan $\mathrm{P}_{9}=$ pemberian $1,8 \mathrm{~kg}$ bokashi $/ 12 \mathrm{~kg}$ tanah, $\mathrm{P}_{10}=$ pemberian $2,0 \mathrm{~kg}$ bokashi $/ 12 \mathrm{~kg}$ tanah, $\mathrm{P}_{11}=$ pemberian $2,2 \mathrm{~kg}$ bokashi $/ 12 \mathrm{~kg}$ tanah, $\mathrm{P}_{12}=$ pemberian $2,4 \mathrm{~kg}$ bokashi $/ 12 \mathrm{~kg}$ tanah. $\mathrm{P}_{13}=$ pemberian $2,6 \mathrm{~kg}$ bokashi $/ 12 \mathrm{~kg}$ tanah (Hanafiah, 1994)

Setelah bibit jambu mete berumur 50 hari, dilakukan pengukuran tinggi batang, berat basah batang, berat kering barang, berat basah daun dan berat kering daun. Data kuantitatif hasil pengukuran parameter di atas dianalisis dengan analisis sidik ragam dan uji lanjut dengan Uji Beda Nyata Terkecil (Gomez dan Gomez, 1995)

\section{HASIL DAN PEMBAHASAN}

\subsection{Hasil Penelitian}

Untuk mengetahui pengaruh aplikasi pupuk organik terhadap pertumbuhan benih jambu mete, dilakukan percobaan yang dilaksanakan di Desa Pijot Kecamatan Keruak Kabupaten Lombok Timur. Setelah tanaman berumur 50 hari dilakukan pengukuran terhadap semua parameter penelitian. Hasil analisis data yang meliputi tinggi batang, berat basah batang, berat kering batang, berat basah dan berat kering daun bibit jambu mete akibat aplikasi pupuk organik terdapat pada tabel 1.

Tabel 1. Rerata berat basah batang, berat kering batang, tinggi batang, berat basah dan berat kering daun jambu mete akibat aplikasi pupuk organik

\begin{tabular}{|c|c|c|c|c|c|}
\hline $\begin{array}{c}\text { Perla- } \\
\text { kuan }\end{array}$ & $\begin{array}{c}\text { Tinggi } \\
\text { Batang }(\mathrm{cm})\end{array}$ & $\begin{array}{c}\text { Berat Basah } \\
\text { Batang (gr) }\end{array}$ & $\begin{array}{c}\text { Berat Kering } \\
\text { Batang (gr) }\end{array}$ & $\begin{array}{c}\text { Berat Basah } \\
\text { Daun (gr) }\end{array}$ & $\begin{array}{c}\text { Berat Kering } \\
\text { Daun (gr) }\end{array}$ \\
\hline $\mathrm{P}_{0}$ & 24 & 52 & 23 & 10 & 4 \\
\hline $\mathrm{P}_{1}$ & 26 & 53 & 25 & 11 & 5 \\
\hline $\mathrm{P}_{2}$ & 29 & 53 & 25 & 11 & 5 \\
\hline $\mathrm{P}_{3}$ & 33 & 54 & 26 & 12 & 6 \\
\hline $\mathrm{P}_{4}$ & 34 & 56 & 26 & 13 & 6 \\
\hline $\mathrm{P}_{5}$ & 35 & 58 & 28 & 14 & 7 \\
\hline $\mathrm{P}_{6}$ & 38 & 60 & 28 & 15 & 7 \\
\hline $\mathrm{P}_{7}$ & 39 & 61 & 29 & 16 & 7 \\
\hline $\mathrm{P}_{8}$ & 40 & 62 & 30 & 17 & 8 \\
\hline $\mathrm{P}_{9}$ & 41 & 62 & 31 & 18 & 8 \\
\hline $\mathrm{P}_{10}$ & 44 & 65 & 33 & 21 & 11 \\
\hline $\mathrm{P} 11$ & 43 & 66 & 32 & 20 & 10 \\
\hline $\mathrm{P} 12$ & 42 & 66 & 33 & 20 & 10 \\
\hline
\end{tabular}




\begin{tabular}{|l|l|l|l|l|l|}
\hline P13 & 43 & 65 & 31 & 19 & 9 \\
\hline
\end{tabular}

\section{Keterangan}

$\mathrm{P}_{0}=$ tampa pemberian bokasi (kontrol)

$\mathrm{P}_{1}=$ Pemberian $0,2 \mathrm{~kg}$ bokasi $/ 12 \mathrm{~kg}$ tanah

$\mathrm{P}_{2}=$ Pemberian $0,4 \mathrm{~kg}$ bokasi $/ 12 \mathrm{~kg}$ tanah

$\mathrm{P}_{3}=$ Pemberian $0,6 \mathrm{~kg}$ bokasi $/ 12 \mathrm{~kg}$ tanah

$\mathrm{P}_{4}=$ Pemberian $0,8 \mathrm{~kg}$ bokasi $/ 12 \mathrm{~kg}$ tanah

$\mathrm{B}_{5}=$ Pemberian $1,0 \mathrm{~kg}$ bokasi $/ 12 \mathrm{~kg}$ tanah

$\mathrm{P}_{6}=$ Pemberian $1,2 \mathrm{~kg}$ bokasi $/ 12 \mathrm{~kg}$ tanah

Selanjutnya untuk mengetahui pengaruh pemberian pupuk organik terhadap semua parameter pertumbuhan maka dilakukan analisis data dengan analisis sidik ragam dan uji lanjut dengan uji beda nyata terkecil (BNT).

Hasil analisis sidik ragam pengaruh pemberian bokashi terhadap semua parameter yang diukur menunjukkan bahwa pemberian bokasi di lahan persawahan Desa Pijot berpengaruh nyata terhadap semua parameter yang diukur

\subsection{Pembahasan}

Hasil analisis data menunjukkan bahwa jambu mete yang tumbuh pada media tanpa pupuk organik memiliki rerata tinggi batang, berat basah batang, berat kering batang, berat basah daun dan berat kering daun masing-masing adalah $24 \mathrm{~cm}, 52$ gr, 23 gr, 10 gr dan 4 gr. Selanjutnya pada polybag yang diberi pupuk organik, rerata semua parameter yang diukur mengalami peningkatan sejalan dengan meningkatnya kadar pupuk organik yang diberikan pada masing-masing unit percobaan. Namun demikian mulai dari perlakuan $2,2 \mathrm{~kg}$ sampai dengan perlakuan $2,6 \mathrm{~kg}$ pupuk organik/12 kg tanah, rerata semua
$\mathrm{P}_{7}=$ Pemberian 1,4 kg bokasi $/ 12 \mathrm{~kg}$ tanah

$\mathrm{P}_{8}=$ Pemberian $1,6 \mathrm{~kg}$ bokasi $/ 12 \mathrm{~kg}$ tanah

$\mathrm{P}_{9}=$ Pemberian $1,8 \mathrm{~kg}$ bokasi $/ 12 \mathrm{~kg}$ tanah

$\mathrm{P}_{10}=$ Pemberian $2,0 \mathrm{~kg}$ bokasi $/ 12 \mathrm{~kg}$ tanah

$\mathrm{P}_{11}=$ Pemberian $2,2 \mathrm{~kg}$ bokasi $/ 12 \mathrm{~kg}$ tanah

$\mathrm{P}_{12}=$ Pemberian $2,4 \mathrm{~kg}$ bokasi $/ 12 \mathrm{~kg}$ tanah

$\mathrm{P}_{13}=$ Pemberian $2,6 \mathrm{~kg}$ bokasi $/ 12 \mathrm{~kg}$ tanah

parameter yang diamati tidak menunjukkan adanya peningkatan secara nyata

Analisis sidik ragam pengaruh pemberian pupuk organik terhadap semua parameter yang diukur menunjukkan bahwa aplikasi pupuk organik di lahan pertanian Desa Pijot berpengaruh nyata terhadap semua parameter yang diukur. Hal ini sejalan dengan hasil penelitian yang dilakukan oleh sejumlah peneliti lainnya yaitu pemanfaatan pupuk organik bokashi dan NPK berpengaruh nyata terhadap laju pertumbuhan daun, berat basah crop dan diameter crop tanaman kubis. Perlakuan bokashi limbah padat pabrik kertas 35 ton/ha dan $200 \mathrm{~kg} / \mathrm{ha}$ pupuk NPK mampu memberikan hasil berat basah crop 1,66 kg/tanaman (Hidayat dan Sugiarti, 2006). Media terbaik untuk pertumbuhan semai eboni adalah pupuk organik EM bokashi karena media ini dapat meningkatkan solubilitas dan viabilitas hara dalam tanah dan memberikan pertumbuhan semai eboni yang optimal (Sumiasri dan Setyowati, 2006). Penambahan bokashi dalam dosis 250 g pada media tanah NPK dapat mendukung pertumbuhan cabe var. Inko 
99 lebih optimal dengan tinggi tanaman $71,15 \mathrm{~cm}$ dan jumlah cabang produktif 40,75 buah (Gustia, 2009). Kedelai varietas galunggung merespon secara signifikan terhadap kompos limbah kelapa sawit, produksi meningkat secara sigifikan (Darma, 2000). Pemupukan dengan pupuk organik Sulfomag plus dapat meningkatkan tinggi dan berat kering tanaman jagung, C-organik, Ntotal tanah dan berat produksi (Chairani, 2005). Pemberian pupuk organik cair dengan konsentrasi $3 \mathrm{mg} / \mathrm{l}-4 \mathrm{mg} / \mathrm{l}$ akan mempengaruhi berat basah dan diameter umbi kentang (Parman, 2007). Pemberian pupuk organik dapat meningkatkan jumlah $\mathrm{N}$ total tanah serta meningkatkan pertumbuhan serta hasil panen jahe (Latifah dan Arifin, 2012). Pemberian pupuk kandang 30 ton/ha yang dikombinasikan dengan kapur 2 ton/ha menghasilkan pertumbuhan tanaman terbaik dengan rataan tinggi tanaman $80,7 \mathrm{~cm}$, jumlah cabang primer 33,4 buah, diameter tajuk 105,7 cm dan produksi terna 25,2 ton/ha. Hasil tersebut berbeda nyata dengan perlakuan control dengan rataan tinggi tanaman $57,3 \mathrm{~cm}$, jumlah cabang primer 20,9 buah, diameter tajuk $67,4 \mathrm{~cm}$ dan produksi terna 6,1 ton/ha (Burhanuddin dan Nurahmansyah, 2010). Pemberian pupuk organik biogreen granul dapat memperbaiki sifat fisik, kimia dan biologi tanah, berpengaruh positif terhadap pertumbuhan dan hasil tanaman bawang merah pada tanah dengan kandungan organik rendah. Pemupukan dengan dosis $4000 \mathrm{~kg} / \mathrm{ha}$ biogreen granul dapat meningkatkan produksi sebesar
$23 \%$ atau selisih hasil sebesar 2,8 ton/ha dibandingkan dengan perlakuan kontrol (Wahyunindyawati dkk, 2012). Pemberian pupuk organik Biogreenex lewat daun dapat meningkatkan kualitas hasil tanaman sawi (kandungan klorofil meningkat $16 \%$, luas daun $76 \%$ dan hasil yang dapat dipasarkan 16\% (Hardjoko, 2002) dan Farida dan Hamdani menyimpulkan, bahwa terdapat interaksi antara pupuk organik bokashi dan pupuk nitrogen terhadap jumlah daun, pemberian pupuk organik bokashi 10 ton/ha berpengaruh baik terhadap komponen kualitas bunga yaitu mampu menghasilkan tangkai bunga terpanjang dan jumlah kuntum bunga terbanyak

Terhambatnya pertumbuhan tanaman pada media tanpa perlakuan pupuk organik disebabkan karena rendahnya ketersedian unsur hara pada media tersebut. Selanjutnya pemberiaan pupuk organik menyebabkan makin tersedianya unsur hara terutama sulfat, posfat dan nitrat yang berasal dari hasil bioprosesing sampah organik yang dijadikan bahan baku pembuatan pupuk organik. Selain itu penambahan pupuk organik dapat memperbaiki sifat biologi, fisika dan kimia tanah. Dengan demikian aplikasi pupuk organik dapat memacu pertumbuhan tanaman.

Stevenson (1996) menjelaskan bahwa hasil dekomposisi bahan organik dalam tanah dapat meningkatkan ketersediaan hara $\mathrm{N}, \mathrm{S}$ dan $\mathrm{P}$, meningkatkan daya menyimpan air, meningkatkan daya buffer tanah, meningkatkan pertukaran kation, dan tekstur tanah menjadi lebih baik. 
Demikian juga joetono (1995) menjelaskan bahwa pada proses dekomposisi bahan organik oleh mikrobia akan dilepaskan unsur hara $\mathrm{N}$, $\mathrm{P}$ dan $\mathrm{S}$ yang dapat digunakan oleh tumbuhan, disamping itu bokasi yang diberikan ke dalam tanah juga dapat memperbaiki sifat fisika, kimia dan biologi tanah. Selanjutnya Santosa (1995) menjelaskan bahwa ketersediaan hara $\mathrm{N}, \mathrm{P}$ dan $\mathrm{S}$ dapat memacu pertumbuhan tanaman. unsur hara $\mathrm{P}$ bagi tanaman berfungsi sebagai penyusun membran plasma, asam nukleat, fosfolipid dan monosakarida sedangkan unsur hara $\mathrm{S}$ berfungsi sebagai penyusun asam amino, vitamin (biotin, thimin) dan coenzim A. Sejalan dengan pendapat di atas Flaigh (1994) menyatakan bahwa pada proses mineralisasi bahan organik oleh mikrobia, dilepaskan hara N, S dan $P$ yang dapat diserap oleh tumbuhan.

Hasil Uji Beda Nyata Terkecil menunjukkan bahwa untuk semua parameter pertumbuhan yang diukur (tinggi batang, berat basah batang, berat kering batang, berat basah daun dan berat kering daun) pada setiap tanaman percobaan, perlakuan $\mathrm{P}_{10}$ (aplikasi 2.0 $\mathrm{kg}$ pupuk organik/12 kg tanah) memberikan hasil yang berbeda nyata dengan $\quad \mathrm{P}_{0} \quad$ (kontrol), selanjutnya perlakuan $\mathrm{P}_{10}$ tidak berbeda nyata dengan perlakuan $\mathrm{P}_{11}$ sampai dengan $\mathrm{P}_{13}$. Hasil analisis tersebut menunjukkan bahwa kadar optimum pupuk organik yang perlu diberikan pada lahan pertanian Desa Pijot Kabupaten Lombok Timur untuk meningkatkan pertumbuhan bibit jambu mete adalah 2,0 kg pupuk organik untuk setiap $12 \mathrm{~kg}$ tanah.

\section{KESIMPULAN}

Berdasarkan hasil analisis data dan pembahasan pada penelitian ini maka dapat disimpulkan bahwa: (1) aplikasi pupuk organik pada lahan pertanian Desa Pijot dapat meningkatkan tinggi batang, berat basah batang, berat kering batang, berat basah daun dan berat kering daun jambu mete. Hal ini menunjukkan bahwa aplikasi pupuk organik pada lahan tersebut dapat meningkatkan pertumbuhan benih jambu mete (2) Penggunaan dosis pupuk organik $2,0 \mathrm{~kg} / 12 \mathrm{~kg}$ tanah memberikan hasil yang lebih baik dibandingkan perlakuan lainnya.

\section{DAFTAR PUSTAKA}

Burhanuddin dan Nurahmansyah. 2010. Pengaruh pemberian pupuk kandang dan kapur terhadap pertumbuhan dan produksi nilam pada tanah podsolik merah kuning. Bul. Littro. 21 (2): 138 144

Chairani. 2005. Pengaruh Pemberian

Pupuk Organik Blotong dan Pupuk Sulfomag Plus Terhadap Sifat Kimia Tanah, Pertumbuhan dan Produksi Tanaman Jagung (Zea mays L.) pada Tanah Typic Paleudult. Respository-usu-acid/bitsream/123456789/15533/1k pt-des2005-(5)pdf. Diakses tanggal 24 Nopember 2012

Darma,S. 2000. Respon tanaman kedelai terhadap kompos limbah kelapa sawit pada dosis berbeda. Jurnal Budidaya Pertanian. 6 (2): $96-104$ 
Farida dan Hamdani, J.S. 2003. Pertumbuhan dan hasil bunga gladiol pada dosis pupuk organik bokashi dan nitrogen yang berbeda. Bionatura. 3(2): 68 - 76

Flaigh, W. 1994. Soil Organic Matter As A Source of Nutrients. I.R.R.I.

Philippines.

Gomez K.A. dan A.A. Gomez. 1995. Prosedur Statistik Untuk penelitian Pertanian Edisi Kedua Penerjemah: Endang Syamsudin dan Justika S. Baharsyah. UI Press. Jakarta.

Gustia, H. 2009. Pengaruh pemberian Bokashi Terhadap pertumbuhan dan produksi tanaman cabe var. inko-99. Akta Agrosia Vol. 12(2): $113-123$.

Hanafiah, 1994. K.A. Rancangan Percobaan. Teori dan Aplikasi. Fakultas Pertanian Universitas Sriwijaya. Palembang.

Hardjoko, D. 2002. Pengkajian Pupuk organik cair biogreenex pada tanaman sawi di Kabupaten Boyolali. Caraka Tani. 15 (2): 9 - 19

Hidayat, F. dan U Sugiarti. 2006. Pemanfaatan Bokashi Limbah Pabrik Kertas Untuk Meningkatkan Pertumbuhan dan Produksi Tanaman Kubis (Brassica oleracea) di Daerah Medium. Laporan Hasil Penelitian. Universitas Widyagama. Malang

Jooetono. 1995. Biologi dan Biokimia Peruraian Bahan organik Tanah. Faperta UGM. Yogyakarta.

Kadir, S. dan M.Z. Karno. 2006. Pengaruh pupuk organik terhadap pertumbuhan dan produksi kopi arabika. www.ijonline.net/index.php/Agri vigor/article/view/i81. diakses tanggal tanggal 16 Februari 2013. Kumalasari, P. 2011. Pemberian Beberapa Dosis Bokashi Salvinia molesta Terhadap Pertumbuhan dan Produksi Tanaman Kedelai (Glycine max L.) Pada Tanah Ultisol. Skripsi. F. MIPA. Universitas Andalas. Padang.

Latifah, E. dan Z. Arifin. 2012. Pengaruh Pemberian Pupuk Organik Terhadap Pertumbuhan dan Hasil Panen Jahe. Jatim.litbang.deptan.go.id/ind/ind ex.

php?option=com_content $\&$ view= article \&id $=549 \&$ ltemid $=10$

diakses tanggal 25 Nopember 2012.

Marliah, A., Nurhayati dan D. Susilawati. 2011. Pengaruh Pemberian Pupuk Organik dan Jenis Mulasa Organik Terhadap Pertumbuhan dan Hasil Kedelai (Glycine $\max$ (L.) Merrill. Jurnalflorestek.wordpress.com/2 011/10/14/pengaruh-pemberianpupuk-organik-dan-jenis-mulsaorganik. Diakses tanggal 25 Nopember 2012.

Parman, S. 2007. Pengaruh pemberian pupuk organik cair terhadap pertumbuhan dan produksi kentang (Solanum tuberosum L.). eprints.undips.ac.id/6188/1/sardja na_P_SOLANUM-KOMPL-pdf.

Diakses tanggal 15 Februari 2013.

Putri, A.I. 2008. Pengaruh Media Organik Terhadap Indeks Mutu Bibit Cendana. www.biotifor.or.id/indexphp?action=publikasi.gendown\&a kt_id=NTl=title=UEVOROFSVU ggTUVESUEgT1. Diakses tanggal 1 Desember 2012 
Santosa, 1995. Ilmu Hara. Fakultas Biologi Universitas Gadjah Mada. Yogyakarta

Simatupang, Y.M.A. 1999. Pengaruh Pemberian Bokashi Kotoran Ayam dan Bokashi Rumput Terhadap Beberapa Sifat Fisika Tanah Podsolik Merah Kuning Gajrug dan Pertumbuhan Tanaman Kedelai (Glycine max L. Merr) varietas Wilis. Skripsi. Fakultas Pertanian Intitut Pertanian Bogor.

Soverda,N., Rinaldy dan I. Susanti. 2008. Pengaruh Beberapa Macam Bokashi Terhadap Pertumbuhan dan Hasil Tanaman Tomat (Lycopersicum esculentum Mill.) Di Polybag. Onlinejournal.unja.id/index.php/agrono mi/article/download/432/348. Diakses tanggal 1 Desember 2013.
Stevenson, F.J. 1994. Humus, Chemystry, Genesis, Compositions, Reactions. John Willy \& Sons. New York

Sumiasri, N. dan N Setyowati. 2006. Pengaruh beberapa media pada pertumbuhan bibit eboni (Diospyros celebica Bakh). melalui perbanyakan biji. Biodipersitas. 7(3):260 - 263.

Teruo, H. 1999. EM Tecnology Indonesian Kyusei Nature Farming Societies \& PT. Songgolangit Persada. Jakarta.

Wahyunindyawati, F. Kasijadi dan Abu. 2012. Pengaruh pemberian pupuk organik biogreen granul terhadap pertumbuhan dan hasil tanaman bawang merah. Jurnal Basic Science and Technology, 1 (1): 21 $-25$. 